Mariusz WISLA

\title{
Valve steel oxidation rate in the exhaust gases of diesel engines fueled with $5 \%$ biocomponent diesel oil
}

\begin{abstract}
Out of the many components of four-stroke diesel engines the exhaust valves are under significant constant thermal and mechanical loads. They operate in a highly corrosive environment of hot exhaust gases. The durability of these elements is determined by the creep resistance of steel i.e. simultaneous resistance to mechanical deformations under high temperatures and the resistance of the surface to corrosive hot exhaust gases.

Long term cyclic heating and burning of the exhaust valves in the exhaust gases whose main components are oxygen, carbon dioxide and superheated steam results in a simultaneous corrosion of the steel surface and core diffusion of carbon and alloy elements in the thin layer of the steel surface. In extreme operating conditions this may lead to a deformation of the exhaust valves, a reduction of the air tightness of the combustion chamber or damage or destruction of the engine.

The paper discuses the results of investigations of the influence of $\mathrm{Cr}, \mathrm{Ni}, \mathrm{Mn}$ and $\mathrm{Si}$ on the oxidation rate of high alloy austenitic valve steel in the diesel oil exhaust gases containing 5\% of biocomponents. The corrosion tests were conducted in the temperate of $973 \mathrm{~K}$ and $1173 \mathrm{~K}$ under the conditions simulating the operation of the exhaust valves in diesel engines under heavy thermal loads.

Based on the conducted research significant influence of the said alloy elements on the oxidation rate of the valve steel in the exhaust gases has been observed. The tests were conducted on the engine durability test stand in Automotive Research and Development Institute BOSMAL in Bielsko-Biała.
\end{abstract}

Key words: valve steel, diesel exhaust gases, oxidation rate

\section{Szybkość utleniania stali zaworowych w gazach spalinowych oleju napędowego z dodatkiem 5\% biokomponentów}

Spośród licznych elementów konstrukcyjnych czterosuwowych silników spalinowych o zapłonie samoczynnym zawory wylotowe należa do silnie obciażonych cieplnie i mechanicznie. Poza tym pracuja w niezwykle agresywnym korozyjnie środowisku gorących gazów spalinowych. O trwałości tych elementów decyduje żarowytrzymatość stali, tj. jednoczesna odporność zaworów na odkształcenia mechaniczne w wysokich temperaturach oraz odporność powierzchni na wysokotemperaturowe korozyjne oddziatywanie goracych gazów spalinowych.

Dlugookresowe cykliczne nagrzewanie i wygrzewanie zaworów wylotowych w atmosferze spalin oleju napędowego, gdzie głównymi składnikami utleniajacymi sa tlen, dwutlenek węgla i przegrzana para wodna, powoduje jednoczesna korozję powierzchni stalowej oraz odrdzeniową dyfuzję węgla i pierwiastków stopowych w cienkiej warstwie przypowierzchniowej stali. W skrajnych warunkach eksploatacyjnych może to prowadzić do odksztatcenia zaworów wylotowych, zmniejszenia szczelności komory spalania i uszkodzenia lub zniszczenia silnika spalinowego.

W artykule omówiono wyniki badań wptywu Cr, Ni, Mn i Si na szybkość utleniania wysokostopowych austenitycznych stali zaworowych $w$ gazach spalinowych oleju napędowego z dodatkiem 5\% biokomponentów. Badania korozyjne prowadzono w temperaturze 973 i $1173 \mathrm{~K} w$ warunkach symulujacych prace zaworów wylotowych w wysokoobciażonych cieplnie silnikach o zaptonie samoczynnym.

Na podstawie przeprowadzonych badań stwierdzono duży wpływ wymienionych pierwiastków stopowych na szybkość utleniania stali zaworowych w gazach spalinowych silnika. Badania wykonano na stanowisku badań trwatościowych silników w Instytucie Badań i Rozwoju Motoryzacji BOSMAL w Bielsku-Białej.

Słowa kluczowe: stal zaworowa, spaliny oleju napędowego, szybkość utleniania

\section{Introduction}

The exhaust valves controlling the air tightness of the combustion chamber and the flow of highly corrosive hot exhaust gases to the exhaust manifold have great impact on the durability and operational parameters of combustion engines and their exhaust systems including catalytic converters.

The measurements of the temperatures of the exhaust valves operating in diesel engines under high thermal and

\section{Wprowadzenie}

Zawory wylotowe, decydując o szczelności komory spalania oraz przepływie niezwykle agresywnych korozyjnie gorących gazów spalinowych do układu wydechowego, wywierają duży wpływ na trwałość i walory eksploatacyjne silników spalinowych oraz układów wydechowych i katalizatorów spalin.

Pomiary temperatur zaworów wylotowych pracujących w wysokoobciążonych cieplnie i mechanicznie silnikach o 
mechanical loads have shown that the exhaust gases flowing out of the cylinder with the velocity of approximately 560 to $670 \mathrm{~m} / \mathrm{s}$ and temperature of approximately $1000 \mathrm{~K}$ to $1273 \mathrm{~K}$ heat up the valve heads of the modern bimetallic exhaust valves in diesel engines to the temperature of approximately $1050 \mathrm{~K}$ [2].

In order to ensure high creep resistance of the exhaust valve i.e. great resistance to heat in a highly corrosive environment of the diesel exhaust gases [3] (Tab. 1) including high resistance to low and high temperature creeping [4] the valve heads of moderns bimetallic exhaust valves are usually made from four types of high alloy austenitic valve steel of the chemical composition and mechanical properties given in Table 2 and 3. zapłonie samoczynnym wykazały, że wypływające z cylindra przez szczelinę wylotową między przylgnią zaworową a gniazdem zaworowym z prędkością od ok. 560 do ok. $670 \mathrm{~m} / \mathrm{s}$ gazy spalinowe o temperaturze od ok. 1000 do ok. $1273 \mathrm{~K}$ nagrzewają grzybki współczesnych bimetalicznych zaworów wylotowych silników o zapłonie samoczynnym do temperatury ok. $1050 \mathrm{~K}$ [2].

W celu zapewnienia wysokiej żarowytrzymałości zaworów wylotowych, tj. wysokiej żaroodporności w silnie utleniającym środowisku gorących gazów spalinowych oleju napędowego [3] (tab. 1) oraz wysokiej odporności na nisko- i wysokotemperaturowe pełzanie [4], grzybki współczesnych bimetalicznych zaworów wylotowych wytwarzane są zazwyczaj z czterech gatunków wysokostopowych austenitycznych

Table 1. Average value of the oxidizers in the diesel exhaust gases [3]

Tabela 1. Średnia zawartość utleniaczy w spalinach silników o zapłonie samoczynnym [3]

\begin{tabular}{|c|c|c|}
\hline \multicolumn{3}{|c|}{ Exhaust gas component, \% vol./składnik gazów spalinowych, \% obj. } \\
\hline Oxygen/tlen & Carbon monoxide/tlenek węgla & Steam/para wodna \\
\hline $2.0-18.0$ & $0.5-4.0$ & $0.01-0.5$ \\
\hline
\end{tabular}

Table 2. Chemical composition of steel used for the production of exhaust valves for gasoline and diesel engines [5]

Tabela 2. Skład chemiczny stali stosowanych do produkcji zaworów wylotowych silników o zapłonie iskrowym i samoczynnym [5]

\begin{tabular}{|c|c|c|c|c|c|c|c|}
\hline \multirow{2}{*}{$\begin{array}{c}\text { Type of steel/ } \\
\text { gatunek stali }\end{array}$} & \multicolumn{7}{|c|}{ Chemical composition/sktad chemiczny, \% } \\
\cline { 2 - 8 } & $\mathrm{C}$ & $\mathrm{Cr}$ & $\mathrm{Ni}$ & $\mathrm{Mn}$ & $\mathrm{Si}$ & $\mathrm{Nb}$ \\
\hline $\mathrm{X} 33 \mathrm{CrNiMn}$ & $0.28-0.38$ & $22.0-24.0$ & $7.00-9.00$ & $1.5-3.5$ & $0.50-1.00$ & - \\
\hline $\mathrm{X} 50 \mathrm{CrMnNiNb}$ & $0.45-0.55$ & $20.0-22.0$ & $3.50-5.50$ & $8.0-10.0$ & $<0.45$ & $1.80-2.50$ & $0.80-1.50$ \\
\hline $\mathrm{X} 53 \mathrm{CrMnNi}$ & $0.48-0.58$ & $20.0-23.0$ & $3.25-4.50$ & $8.0-10.0$ & $<0.25$ & - \\
\hline $\mathrm{X} 55 \mathrm{CrMnNi}$ & $0.50-0.60$ & $19.5-21.5$ & $1.50-2.75$ & $7.0-10.0$ & $<0.25$ & - \\
\hline
\end{tabular}

Table 3. Mechanical properties of valve steel in the ambient temperature [5]

Tabela 3. Właściwości mechaniczne stali zaworowych w temperaturze pokojowej [5]

\begin{tabular}{|c|c|c|c|c|c|c|}
\hline \multirow{2}{*}{$\begin{array}{l}\text { Type of steel/ } \\
\text { gatunek stali }\end{array}$} & \multirow{2}{*}{$\begin{array}{c}\text { Thermal processing/ } \\
\text { obróbka cieplna }\end{array}$} & \multirow[t]{2}{*}{ Structure/struktura } & \multicolumn{4}{|c|}{ Mechanical properties/właściwości mechaniczne } \\
\hline & & & $\begin{array}{c}\mathrm{Rm} \\
{\left[\mathrm{N} / \mathrm{mm}^{2}\right]}\end{array}$ & $\begin{array}{l}\operatorname{Re}_{(0.2) \min } . \\
{\left[\mathrm{N} / \mathrm{mm}^{2}\right]}\end{array}$ & $\begin{array}{l}\mathrm{A}_{\min } \\
{[\%]} \\
\%\end{array}$ & $\begin{array}{l}Z_{\min } \\
{[\%]}\end{array}$ \\
\hline $\mathrm{X} 33 \mathrm{CrNiMn}$ & \multirow{4}{*}{$\begin{array}{c}\text { Quenched and aged/ } \\
\text { przesycony } \\
\text { i starzony }\end{array}$} & \multirow{4}{*}{$\begin{array}{l}\text { Austenite with miniscule evolution } \\
\text { of high-dispersion M23C6 carbides/ } \\
\text { austenit z drobnymi o dużej dyspersji } \\
\text { wydzieleniami węglików typu M23C6 }\end{array}$} & $880-1080$ & 540 & 10 & 10 \\
\hline $\mathrm{X} 50 \mathrm{CrMnNiNb}$ & & & $950-1200$ & 600 & 8 & 10 \\
\hline $\mathrm{X} 53 \mathrm{CrMnNi}$ & & & $980-1180$ & 590 & 8 & 10 \\
\hline $\mathrm{X} 55 \mathrm{CrMnNi}$ & & & $980-1180$ & 590 & 8 & 10 \\
\hline
\end{tabular}

Numerous durability tests conducted in Automotive Research and Development Institute BOSMAL in Bielsko-Biała on gasoline and diesel combustion engines and the analyses of the reasons for the damage of the exhaust valves have shown that one of the important causes of destruction of the exhaust valves under heavy thermal and mechanical loads, aside from the defective structure of the padded stellite on the valve seat, may be the process of long term burning in a highly oxidizing environment of the hot exhaust gases. The conditions of cyclically variable tensions and thermal shocks as well as surface oxidation and diffusive decrement of the stali zaworowych, o składzie chemicznym oraz właściwościach mechanicznych podanych w tab. 2 i 3.

Prowadzone w Instytucie Badań i Rozwoju Motoryzacji BOSMAL w Bielsku-Białej liczne badania trwałościowe silników spalinowych o zapłonie iskrowym i samoczynnym oraz analizy przyczyn uszkodzenia zaworów wylotowych wykazały, że jedną z ważnych przyczyn niszczenia wysokoobciążonych cieplnie i mechanicznie zaworów wylotowych, poza wadliwą strukturą warstwy napawanego na przylgnie zaworowe stellitu, może być także proces długookresowego wygrzewania zaworów w silnie utleniającym środowisku 


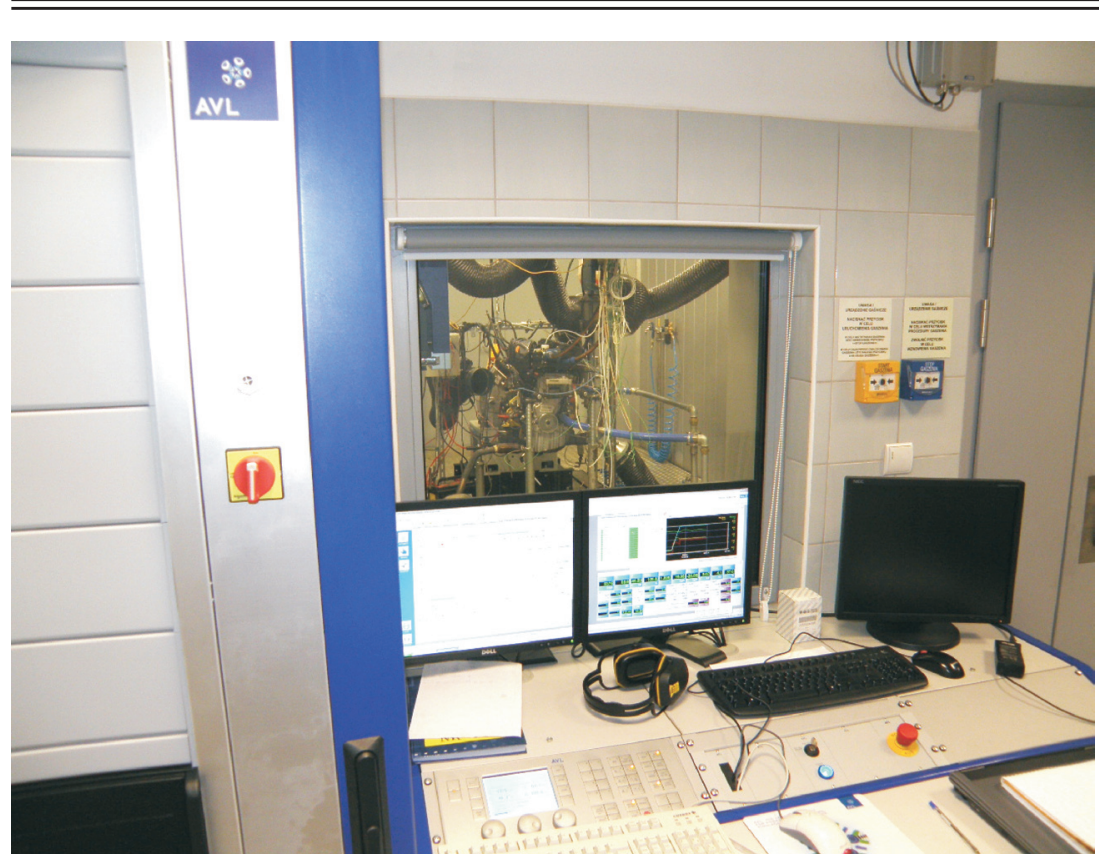

Fig. 1. Gasoline and diesel combustion engines test bed in Automotive Research and Development Institute BOSMAL Sp. z o. o. in Bielsko-Biała

Rys. 1. Stanowisko do badań silników spalinowych o zapłonie iskrowym i samoczynnym w Instytucie Badań i Rozwoju Motoryzacji BOSMAL Sp. z o. o. w Bielsku-Białej

concentration of carbon and other alloy elements in the thin surface layers of steel may lead to a reduction of the working diameter of the valve plates and heads and subsequently to a deformation of the exhaust valves, hence a damage or destruction of the whole engine (Fig. 1).

\section{Own research}

The investigations into the rate of oxidation of valve steel in the exhaust gases of a turbocharged four-cylinder diesel engine were conducted on the samples in the form of disks of the diameter of approximately 16 and $19 \mathrm{~mm}$ and the thickness of approximately $1 \mathrm{~mm}$. The samples were taken through turning bars of the diameters of approximately 17 and $20 \mathrm{~mm}$ respectively. The bars were made from industrial high alloy austenitic valve steel X33CrNiMnN238, $\mathrm{X} 53 \mathrm{CrMnNiN} 208$ and $\mathrm{X} 55 \mathrm{CrMnNiN} 208$ of the chemical composition given in Table 4.

The Samples tested for the oxidation rate after boring holes $\Phi 2$ at a distance of approximately $2 \mathrm{~mm}$ from the edge were sanded and buffed using appropriate sand papers and abrasive compounds, cleaned with methanol and dried with pressurized air. After the said actions the samples were measured with a caliper (accuracy $0.01 \mathrm{~mm}$ ) and weighed (accuracy $10^{-4} \mathrm{~g}$ ) in an air-conditioned room. Then the samples gorących gazów spalinowych. W warunkach cyklicznie zmiennych naprężeń i wstrząsów cieplnych oraz jednoczesnego powierzchniowego utleniania i dyfuzyjnego zmniejszenia stężenia węgla i pierwiastków stopowych w cienkich warstwach przypowierzchniowych stali może on prowadzić do zmniejszenia przekroju czynnego talerzyków i grzybków zaworowych, a następnie do odkształcenia zaworów wylotowych i uszkodzenia lub zniszczenia silnika spalinowego (rys. 1).

\section{Badania własne}

Badania szybkości utleniania stali zaworowych w gazach spalinowych turbodoładowanego czterocylindrowego silnika o zapłonie samoczynnym prowadzono na próbkach w postaci dysków o średnicy ok. 16 i $19 \mathrm{~mm}$ i grubości ok. $1 \mathrm{~mm}$. Próbki pobrano metodą toczenia z prętów o średnicy odpowiednio ok. 17 i $20 \mathrm{~mm}$ z przemysłowego wytopu wysokostopowych austenitycznych stali zaworowych X33CrNiMnN238, X53CrMnNiN208 i X55CrMnNiN208 o składzie chemicznym podanym w tab.4.

Próbki do badań szybkości utleniania po nawierceniu otworków $\Phi 2$ w odległości ok. 2 mm od krawędzi szlifowano i polerowano $z$ wykorzystaniem odpowiednich papierów i past polerskich, po czym myto alkoholem metylowym i suszono w strumieniu sprężonego powietrza. Po wymienionych zabiegach próbki mierzono suwmiarką z dokładnością 0,01 mm i ważono z dokładnością $10^{-4} \mathrm{~g}$ w klimatyzowanym pomieszczeniu, a następnie wieszano na kanthalowych haczykach i wraz z oprzyrządowaniem wkładano do szklanej rury reaktora (rys. 2).

Utlenianie próbek w gazach spalinowych oleju napędowego z dodatkiem 5\% biokomponentów, tj. estrów metylowych wyższych kwasów tłuszczowych, prowadzono w warunkach kolejnych cyklicznych wstrząsów cieplnych. Symulowano pracę zaworów wylotowych w silniku o zapłonie samoczynnym przez szybkie nagrzewanie próbek w reaktorze do temperatury $973 \mathrm{~K}$ oraz do temperatury $1173 \mathrm{~K}$, po czym wygrzewano próbki w wymienionych temperaturach przez 2 godz. i chłodzono przez 25 min w temperaturze pokojowej (rys. 3).

Natomiast szybkość utleniania stali zaworowych w warunkach cyklicznych wstrząsów cieplnych [6] w gazie

Table 4. The chemical composition of the tested valve steel types

Tabela 4. Skład chemiczny badanych stali zaworowych

\begin{tabular}{|c|c|c|c|c|c|c|c|c|c|c|}
\hline \multirow{2}{*}{ Steel/stal } & \multicolumn{10}{|c|}{ Chemical composition/sktad chemiczny, \% } \\
\cline { 2 - 13 } & $\mathrm{C}$ & $\mathrm{Cr}$ & $\mathrm{Ni}$ & $\mathrm{Mn}$ & $\mathrm{Si}$ & $\mathrm{Mo}$ & $\mathrm{W}$ & $\mathrm{N}$ & $\mathrm{S}$ & $\mathrm{P}$ \\
\hline X33CrNiMn N238 & 0.35 & 23.40 & 7.82 & 3.30 & 0.63 & 0.11 & 0.02 & 0.28 & $<0.005$ & 0.014 \\
\hline X53CrMnNi N208 & 0.53 & 20.50 & 4.10 & 10.30 & 0.30 & 0.12 & - & 0.41 & $<0.005$ & 0.040 \\
\hline X55CrMnNi N208 & 0.55 & 20.30 & 2.08 & 7,57 & 0.17 & 0.11 & - & 0.38 & $<0.005$ & 0.040 \\
\hline
\end{tabular}




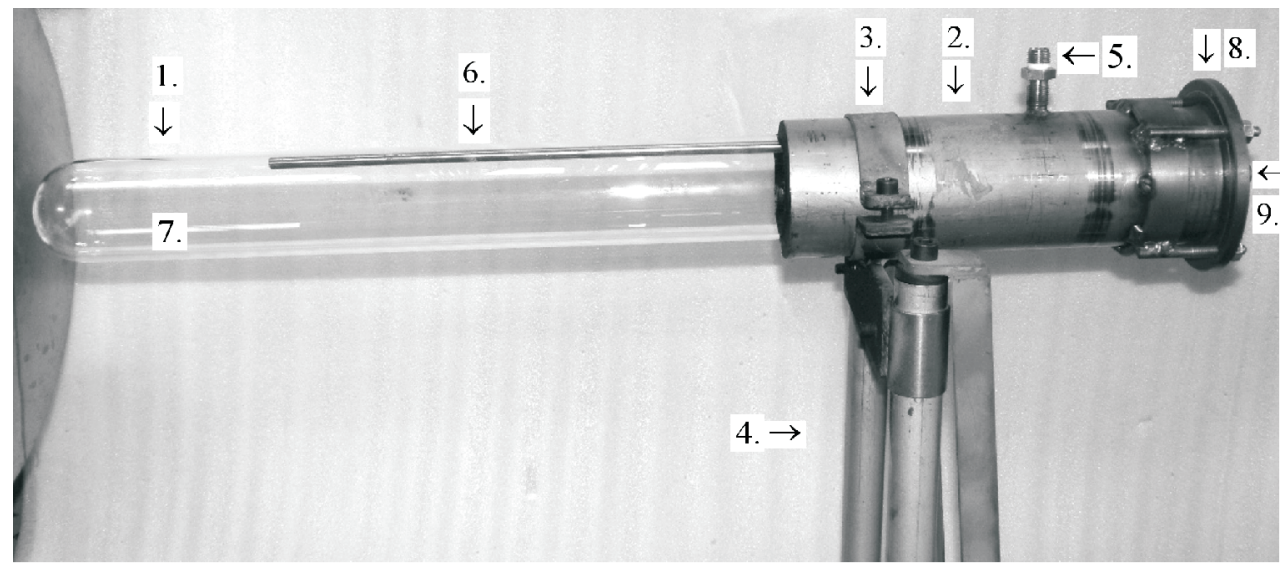

Fig. 2. Reactor for the testing of the oxidation rate of valve steel in the diesel exhaust gases: 1 - reactor, 2 - steel reactor case, 3 - mounting of the reactor to the support, 4 - support fixing and leveling the reactor, 5 - exhaust gases feed to the reactor, 6 - steel pipe distributing the exhaust gases in the reactor, 7 - sample oxidation spot, 8 - bolt-fixed input window, 9 - exhaust gases outlet

Rys. 2. Reaktor do badania szybkości utleniania stali zaworowych w gazach spalinowych silnika o zapłonie samoczynnym: 1 - reaktor, 2 - stalowa obudowa reaktora, 3 - uchwyt mocujacy reaktor do stojaka, 4 - stojak mocujacy $i$ poziomujacy reaktor, 5 - doprowadzenie spalin do reaktora, 6 - stalowa rurka rozprowadzajaca spaliny $w$ reaktorze,

7 -miejsce utleniania próbek, 8 - mocowane śrubami okno wsadowe, 9-odprowadzenie spalin

were hung on a kanthal hooks and together with the testing equipment put in the glass pipe of the reactor (Fig. 2).

The oxidation of the samples in the diesel exhaust gases with the $5 \%$ content of biocomponents i.e. methyl esters of higher fatty acids, were conducted in the conditions of subsequent thermal shocks. The operation of the diesel engine exhaust valves was simulated through a quick heating up of the samples in the reactor to the temperature of $973 \mathrm{~K}$ and $1173 \mathrm{~K}$. The samples were burned in these temperatures for two hours and subsequently chilled for $25 \mathrm{~min}$ in the ambient temperature (Fig. 3).

The valve steel oxidation rate under the conditions of cyclic thermal shocks [6] in the diesel exhaust gases with the $5 \%$ content of biocomponents was analyzed with the method of increment or decrement of the sample mass as a function of oxidation time (commonly applied in research into metal and alloy oxidation kinetics) $[7,8]$. The mass of the tested samples was measured in the preset time intervals i.e. every 25 hours up to 200 hours of oxidation and then every 50 hours until the end of the oxidation process. The oxidized samples after removal from the reactor chamber were chilled to the ambient temperature, cleaned from the scales with pressurized air and weighed in an air-conditioned room (accuracy $10^{-4} \mathrm{~g}$ ). The oxidation rate of the tested valve steel was determined through the measurement of the increment or decrement of the mass of the tested samples $\Delta \mathrm{m}$ in relation to the initial surface parameters of samples $\mathrm{S}$ in $\left[\mathrm{g} / \mathrm{cm}^{2}\right]$. The measurement results were compared to oxidation time $\mathrm{t}$ [hours] in the reactor chamber. spalinowym oleju napędowego z dodatkiem 5\% biokomponentów analizowano, powszechnie stosowaną w badaniach kinetyki utleniania metali i stopów, metodą pomiaru przyrostu lub ubytku masy próbek w funkcji czasu utleniania [7, 8]. Masę utlenianych próbek badano w z góry ustalonych odstępach czasu, tj. co 25 godz. do 200 godz. utleniania i dalej co 50 godz. do końca procesu utleniania. Utleniane próbki po wyjęciu z komory reaktora chłodzono do temperatury pokojowej, po czym czyszczono strumieniem sprężonego powietrza $z$ odpadającej zgorzeliny i ważono w klimatyzowanym pomieszczeniu $\mathrm{z}$ dokładnością $10^{-4} \mathrm{~g}$. Szybkość utleniania badanych stali zaworowych wyznaczano, mierząc przyrost lub ubytek masy utlenianych próbek $\Delta \mathrm{m}$ w odniesieniu do powierzchni początkowej próbek $\mathrm{S} w\left[\mathrm{~g} / \mathrm{cm}^{2}\right]$, a nastepnie wyniki pomiarów odnoszono do czasu utleniania próbek $\mathrm{t}$ [godz.] w komorze roboczej reaktora.

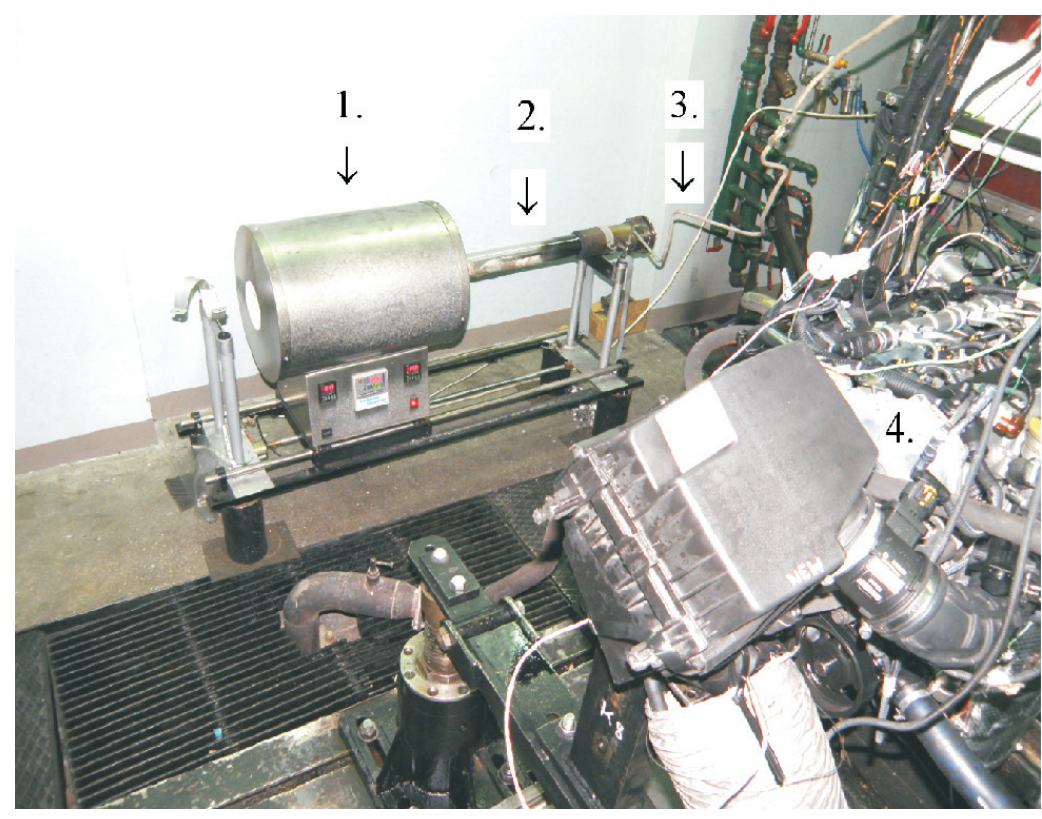

Fig. 3. Test stand for the testing of the oxidation rate of valve steel in the diesel exhaust gases: 1 - reactor heater, 2 - reactor, 3 - pipe feeding the exhaust gases from the manifold to the reactor, 4 - diesel engine on the durability test stand

Rys. 3. Stanowisko do badań szybkości utleniania stali zaworowych w gazach spalinowych oleju napędowego: 1 - piec nagrzewający reaktor, 2 - reaktor, 3 -rurka doprowadzajaca spaliny z kolektora spalin do reaktora, 4 - silnik o zapłonie samoczynnym na stanowisku badań trwałościowych 


\section{Discussion}

The conducted tests of the oxidation kinetics of high alloy valve steel X33CrNiMnN238, X53CrMnNiN208 and $\mathrm{X} 55 \mathrm{CrMnNiN} 208$ in the diesel exhaust gases have shown an extremely low oxidation rate of the steel with the lowest mechanical parameters $\mathrm{X} 33 \mathrm{CrNiMnN} 238$ and highest content of $\mathrm{Cr}$, Ni and $\mathrm{Si}(23.40 ; 7.82$ and $0.63 \%$ respectively) as well as of

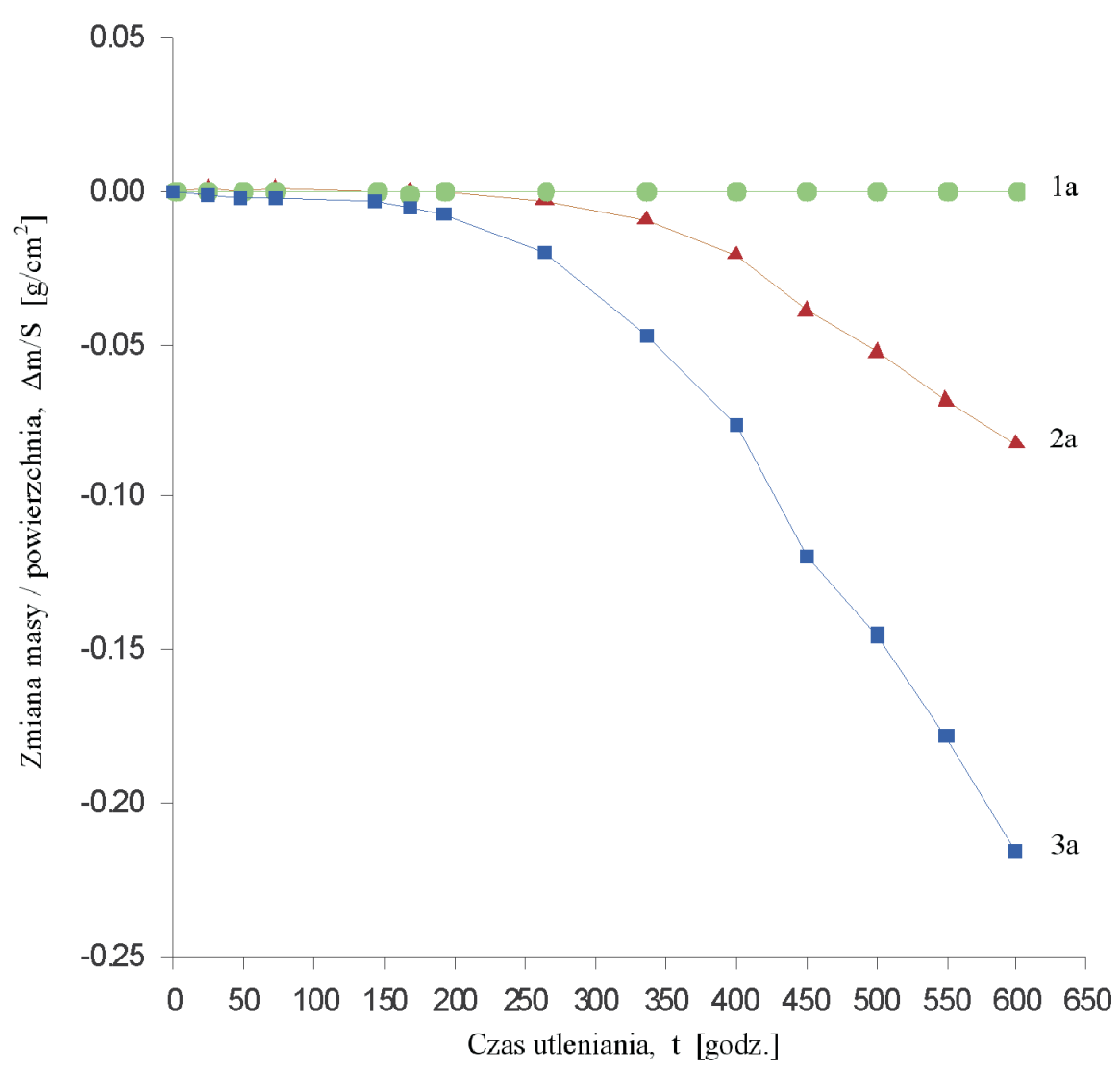

Fig. 4. The oxidation rate of high alloy austenitic valve steel: $1 \mathrm{a}-\mathrm{X} 33 \mathrm{CrNiMnN} 238,2 \mathrm{a}-\mathrm{X} 53 \mathrm{CrMn}-$ NiN208, 3a - X55CrMnNiN208. The samples were oxidized in diesel exhaust gases with 5\% content of biocomponents under the conditions of cyclic thermal shocks at the temperature of $973 \mathrm{~K} / 600$ hours

Rys. 4. Szybkość utleniania wysokostopowych austenitycznych stali zaworowych: $1 a-X 33 C r-$ NiMnN238, 2a-X53CrMnNiN208, 3a-X55CrMnNiN208. Próbki utleniano w gazie spalinowym oleju napędowego z dodatkiem 5\% biokomponentów $w$ warunkach cyklicznych wstrzasów cieplnych w temperaturze $973 \mathrm{~K} / 600$ godz.

\section{Omówienie wyników badań}

Przeprowadzone badania kinetyki utleniania wysokostopowych austenitycznych stali zaworowych X33CrNiMnN238, X53CrMnNiN208 i X55CrMnNiN208 w gazach spalinowych wykazały niezwykle małą szybkość utleniania stali o najniższych, spośród badanych stali zaworowych, właściwościach mechanicznych X33CrNiMnN238 i największej zawartości $\mathrm{Cr}$, Ni i Si (odpowiednio 23,40; 7,82 i 0,63\%) oraz najmniejszej zawartości manganu 3,30\%. Badania kinetyki utleniania wykazały, że w początkowym okresie procesu utleniania szybkość utleniania stali X33CrNiMnN238 mierzona zmianą masy próbek w funkcji czasu utleniania w temperaturze $973 \mathrm{~K}$ zwiększa się niezwykle lagodnie, tj. o ok. $0,0002 \mathrm{~g} / \mathrm{cm}^{2}$ po 72 godz. utleniania, po czym pozostaje niezmienna, pomimo dalszego zwiększania czasu utleniania do 600 godz. i liczby wstrząsów cieplnych do ok. 250 cykli (rys. 4 krzywa 1a i rys. 5). Większe szybkości utleniania w gazach spalinowych w temperaturze $973 \mathrm{~K}$ wykazały natomiast stale o nieco wyższych właściwościach mechanicznych X53CrMnNiN208 i X55CrMnNiN208 oraz odpowiednio mniejszej zawartość chromu 20,50 i $20,30 \%$, niklu odpowiednio 4,10 i $2,08 \%$ i krzemu 0,30 i 0,17\%, oraz odpowiednio większej zawartości manganu 10,30 i 7,57\%. Badania wykazały, że średni ubytek masy próbek wykonanych ze stali X53CrMnNiN208 i X55CrMnNiN208 w wyniku kolejnych wstrząsów cieplnych oraz intensywnego pękania i odpadania zgorzeliny zwiększał się parabolicznie odpowiednio do ok. 0,0824 $\mathrm{g} / \mathrm{cm}^{2}$ i do ok. 0,2155 g/ $\mathrm{cm}^{2}$ wraz z

the lowest content of manganese $(3.30 \%)$. The tests on the oxidation kinetics have shown that in the initial phase of the oxidation process the oxidation rate of $\mathrm{X} 33 \mathrm{CrNiMnN} 238$ measured through the change of the sample mass as a function of oxidation time in the temperature of $973 \mathrm{~K}$ increases extremely smoothly i.e. by approximately $0,0002 \mathrm{~g} / \mathrm{cm}^{2}$ after 72 hours of oxidation and then remains unchanged despite further extension of the oxidation time to 600 hours and the number of thermal shocks to approximately 250 cycles (Fig. 4 curve $1 \mathrm{a}$ and Fig. 5). Greater oxidation rates in the diesel

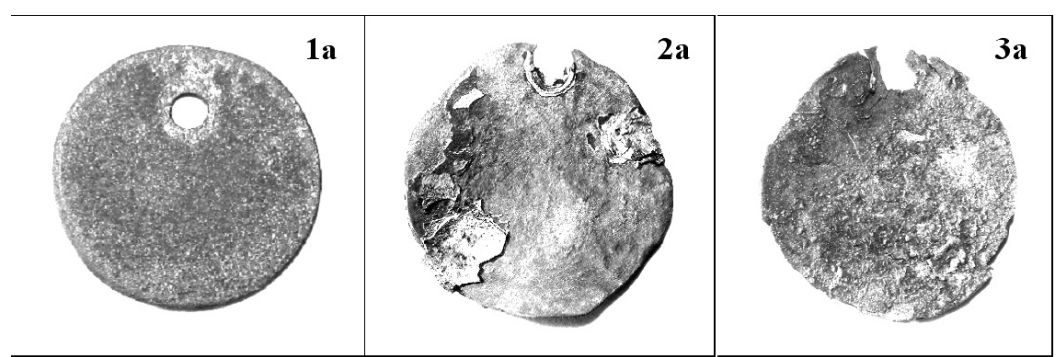

Fig. 5. Macroscopic image of the surface of the tested samples after oxidation in the diesel exhaust gases in the temperature of $973 \mathrm{~K} / 600 \mathrm{hrs}$.: 1a - X33CrNiMnN238, 2a - X53CrMnNiN208, 3a-X55CrMnNiN208

Rys. 5. Makroskopowy obraz powierzchni próbek po utlenieniu w gazie spalinowym oleju

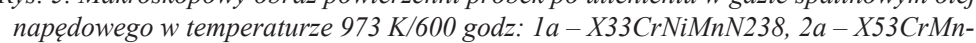
NiN208, 3a-X55CrMnNiN208 
exhaust gases in the temperature of $973 \mathrm{~K}$ occurred for steel types of higher mechanical parameters - X53CrMnNiN208 and $\mathrm{X} 55 \mathrm{CrMnNiN} 208$ of lower chromium content (20.50 and $20.30 \%$ respectively), nickel (4.10 and $2.08 \%$ respectively), silicon ( 0.30 and $0.17 \%$ respectively) and higher content of manganese (10.30 and $7.57 \%$ respectively). The tests have shown that an average decrement of mass of the samples made from X53CrMnNiN208 and X55CrMnNiN208 as a result of subsequent thermal shocks and intense cracking and chipping off of the scales increased parabolically to approximately $0.0824 \mathrm{~g} / \mathrm{cm}^{2}$ and $0.2155 \mathrm{~g} / \mathrm{cm}^{2}$ respectively along with a simultaneous increase of the oxidation time to 600 hours and the cyclic thermal shocks to 250 (Fig. 4 curves $2 \mathrm{a}$ and $3 \mathrm{a}$ respectively and Fig. 5).

Further analysis of the oxidation kinetics of the valve steel X33CrNiMnN238, X53CrMnNiN208 and X55CrMnNiN208 has shown minuscule influence of the temperature of the diesel exhaust gases from $973 \mathrm{~K}$ to $1173 \mathrm{~K}$ on the oxidation rate of steel of the highest $\mathrm{Cr}$, $\mathrm{Ni}$ and $\mathrm{Si}$ content and the lowest content of Mn i.e. high alloy austenitic valve steel $\mathrm{X} 33 \mathrm{CrNiMnN238}$. The analysis of the oxidation kinetics has shown that in the beginning of the oxidation process in the

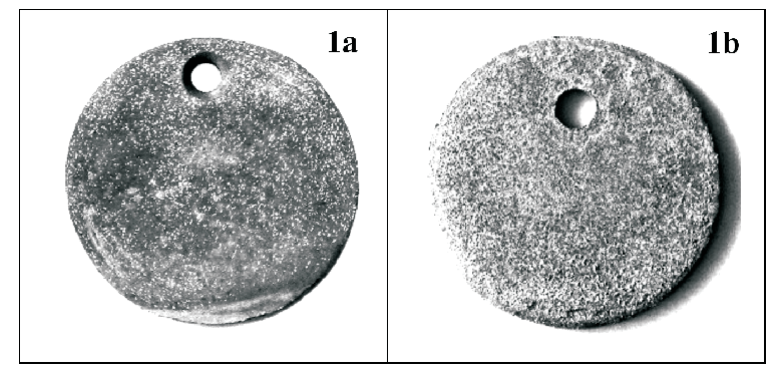

Fig. 7. Macroscopic image of the surface of the $\mathrm{X} 33 \mathrm{CrNiMnN} 238$ samples after oxidation in the diesel exhaust gases in the temperature of 1a $973 \mathrm{~K} / 600$ hours and $1 \mathrm{~b}-1173 \mathrm{~K} / 550$ hours

Rys. 7. Makroskopowy obraz powierzchni próbek stali zaworowej X33CrNiMnN238 po utlenieniu $w$ gazie spalinowych oleju napędowego $z$ dodatkiem 5\% biokomponentów w temperaturze: 1 a - 973 K/600 godz. i $1 b-1173 \mathrm{~K} / 550 \operatorname{godz}$

temperature of $1173 \mathrm{~K}$ the average mass of the samples made from the said steel increased smoothly by approximately $0.00056 \mathrm{~g} / \mathrm{cm}^{2}$ after 72 hours of oxidation and then the average mass of the samples reduced smoothly as the oxidation time was extended to 150 hours. After another 50 hours of oxidation an abrupt reduction of the mass occurred to the mass of approximately $0.0151 \mathrm{~g} / \mathrm{cm}^{2}$. Further extension of the oxidation time in the exhaust gases resulted in an extremely smooth decrement of the average mass of the samples to approximately $0.0234 \mathrm{~g} / \mathrm{cm}^{2}$ after 550 hours of oxidation in the temperature of $1173 \mathrm{~K}$ (Fig. 6 curve $1 \mathrm{~b}$ and Fig.7).

The increase in the temperature of the diesel exhaust gases by $100 \mathrm{~K}$ i.e. from 973 to $1173 \mathrm{~K}$ exerted an extremely strong influence on the oxidation rate of steel of slightly higher mechanical properties - X53CrMnNiN208 and X55CrMnNiN208 and lower content of chromium (20.50 and $20.30 \%$ respectively), nickel ( 4.10 and $2.08 \%$ respectively) silicon ( 0.30 and $0.17 \%$ respectively) and higher content

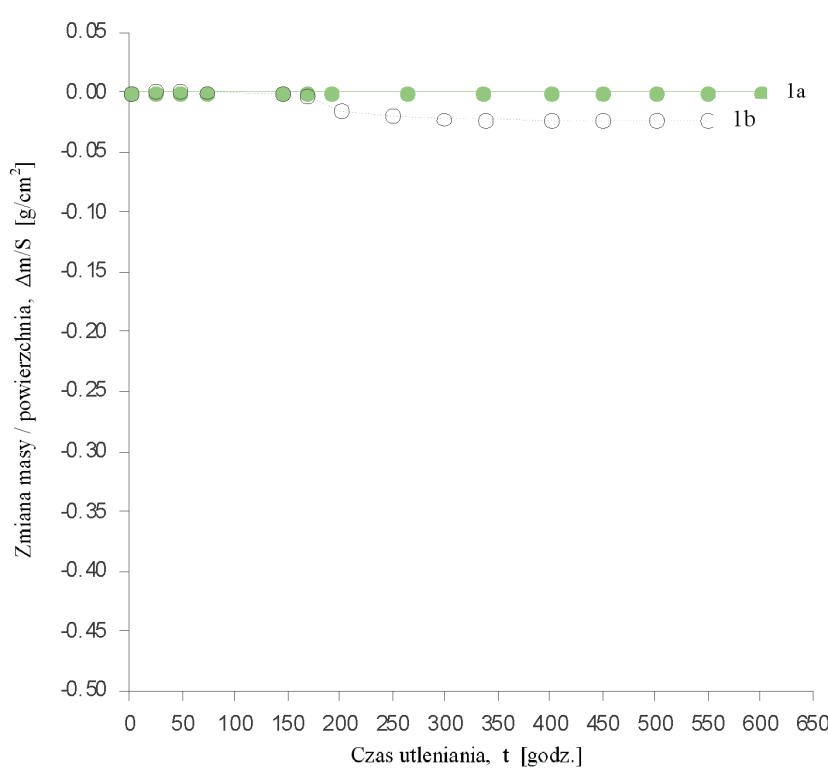

Fig. 6. The oxidation rate of high alloy austenitic valve steel $\mathrm{X} 33 \mathrm{CrNi}$ $\mathrm{MnN} 238$. The samples were oxidized in diesel exhaust gases with 5\% content of biocomponents under the conditions of cyclic thermal shocks at the temperature of $1 \mathrm{a} 973 \mathrm{~K} / 600$ hours and $1 \mathrm{~b}-1173 \mathrm{~K} / 550$ hours

Rys. 6. Szybkość utleniania wysokostopowej austenitycznej stali zaworowej X33CrNiMnN238 w gazie spalinowym oleju napędowego $z$ dodatkiem 5\% biokomponentów $w$ warunkach cyklicznych wstrząsów cieplnych w temperaturze: $1 a-973 \mathrm{~K} / 600$ godz. i $1 \mathrm{~b}-1173 \mathrm{~K} / 550 \mathrm{godz}$.

jednoczesnym zwiększeniem czasu utleniania do 600 godz. oraz cyklicznych wstrząsów cieplnych do 250 cykli (rys.4 krzywe odpowiednio 2a i 3a i rys.5):

Dalsza analiza kinetyki utleniania stali zaworowych X33CrNiMnN238, X53CrMnNiN208 i X55CrMnNiN208 wykazała natomiast niewielki wpływ podwyższenia temperatury gazów spalinowych oleju napędowego z 973 K do 1173 K na szybkość utleniania stali o największej zawartości $\mathrm{Cr}$, Ni i Si oraz najmniejszej zawartości Mn, tj. wysokostopowej austenitycznej stali zaworowej X33CrNiMnN238. Analiza kinetyki utleniania wykazała, że w początkowym okresie procesu utleniania w temperaturze $1173 \mathrm{~K}$ średnia masa próbek wykonanych z wymienionej stali zaworowej zwiększyła się łagodnie o ok. $0,00056 \mathrm{~g} / \mathrm{cm}^{2}$ po 72 godz. utleniania, po czym średnia masa próbek zmniejszała się początkowo łagodnie wraz ze zwiększeniem czasu utleniania do 150 godz. Po upływie kolejnych 50 godz. utleniania nastąpiło skokowe zmniejszenie masy próbek do wartości ok. 0,0151 g/ $\mathrm{cm}^{2}$. Dalsze zwiększanie czasu utleniania próbek w gazach spalinowych powodowało natomiast niezwykle łagodny ubytek średniej masy próbek do ok. 0,0234 $\mathrm{g} / \mathrm{cm}^{2}$ po 550 godz. utleniania w temperaturze $1173 \mathrm{~K}$ (rys.6 krzywa 1 b i rys.7).

Podwyższenie temperatury gazów spalinowych oleju napędowego o $100 \mathrm{~K}$, tj. z 973 do $1173 \mathrm{~K}$, wywarło niezwykle silny wpływ na szybkość utleniania stali o nieco wyższych właściwościach mechanicznych X53CrMnNiN208 i X55CrMnNiN208 oraz mniejszej zawartość chromu odpowiednio 20,50 i 20,30\%, niklu 4,10 i 2,08\% i krzemu 0,30 i $0,17 \%$ oraz większej zawartości manganu odpowiednio 10,30 i 7,57\%. Próbki w wyniku kolejnych cyklicznych 


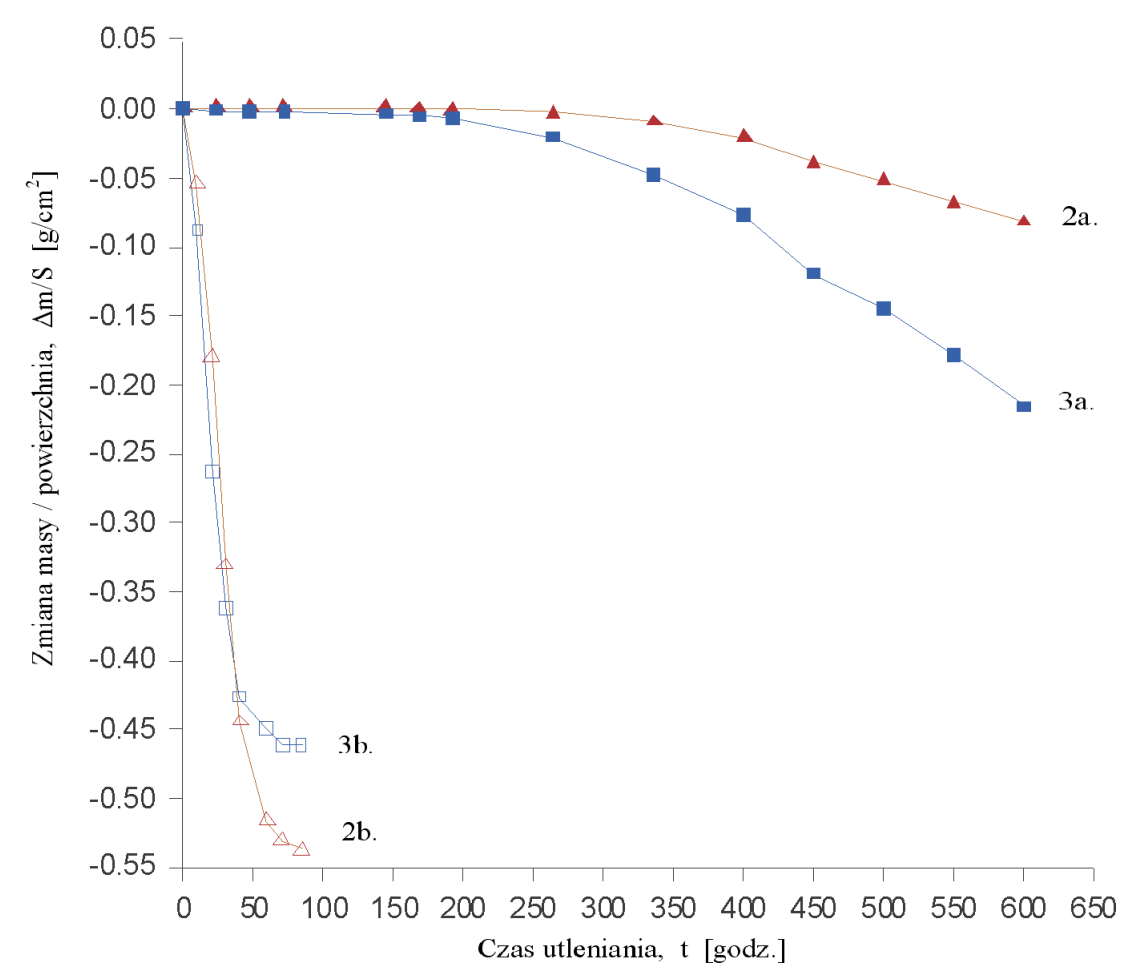

Fig. 8. Oxidation rate of high alloy valve steel: 2 - X53CrMnNiN208 and $3-\mathrm{X} 55 \mathrm{CrMnNiN} 208$ in the diesel exhaust gases with $5 \%$ content of biocomponents under the conditions of cyclic thermal loads in the temperature of: $\mathrm{a}-973 \mathrm{~K} / 600$ hours and $\mathrm{b}-1173 \mathrm{~K} / 80$ hours

Rys. 8. Szybkość utleniania wysokostopowych stali zaworowych:

2 - X53CrMnNiN208 i 3 - X55CrMnNiN208 w gazie spalinowym oleju napędowego z dodatkiem

5\% biokomponentów $w$ warunkach cyklicznych wstrząsów cieplnych $w$ temperaturze: $a-973$ $\mathrm{K} / 600 \operatorname{godz}$. $i \mathrm{~b}-1173 \mathrm{~K} / 80 \operatorname{godz}$.

of manganese (10.30 and $7.57 \%$ respectively). The samples as a result of subsequent cyclic thermal shocks and intense cracking and chipping off of the scales in the exhaust gases in the temperature of $1173 \mathrm{~K}$ were entirely destroyed after approximately 80 hours of oxidation i.e. after approximately 33 thermal cycles (Fig. 8 curves 2 b and $3 b$ and Fig. 9).

\section{Conclusions}

The performed investigations into the oxidation rate of high alloy austenitic valve steel X33CrNiMnN238, X53CrMnNiN208 and X55CrMnNiN208 in the diesel wstrząsów cieplnych oraz intensywnego pękania i odpadania zgorzeliny w gazach spalinowych o temperaturze $1173 \mathrm{~K}$ uległy całkowitej destrukcji po ok. 80 godzinach utleniania, tj. po ok. 33 cyklach cieplnych (rys. 8 krzywe odpowiednio 2 b i 3 b i rys. 9).

\section{Podsumowanie}

Przeprowadzone badania szybkości utleniania wysokostopowych austenitycznych stali zaworowych X33CrNiMnN238, X53CrMnNiN208 i X55CrMnNiN208 w gazach spalinowych oleju napędowego $\mathrm{z}$ dodatkiem $5 \%$ estrów metylowych wyższych kwasów tłuszczowych wykazały, że najmniejszą szybkość utleniania $\mathrm{w}$ warunkach cyklicznych wstrząsów cieplnych w temperaturze $973 \mathrm{~K}$ i $1173 \mathrm{~K}$ ma stal o najniższych, spośród badanych stali zaworowych, właściwościach mechanicznych X33CrNiMnN238 oraz największej zawartości $\mathrm{Cr}, \mathrm{Ni}$ i Si odpowiednio 23,$40 ; 7,82$ i $0,63 \%$ oraz najmniejszej zawartości Mn 3,30\% (rys. 9 krzywa odpowiednio 1a i 1b).

Badania szybkości utleniania wykazały także, że jednoczesne zwiększenie zawartości Mn z 3,30\% do 10,30 i $7,57 \%$ [9] oraz zmniejszenie zawartości Cr z od 23,40\% do 20,50 i 20,30\%, tj. do wartości mniejszych od stężenia zapewniającego selektywne utlenianie $\mathrm{Cr}[10,11]$ oraz zmniejszenie zawartości zwiększającego współczynnik dyfuzji $\mathrm{Cr}$ w stali $\mathrm{Ni}$ z od 7,82\% do 4,10 i $2,08 \%$ [12] i Si z od $0,63 \%$ do 0,30 i $0,17 \%$ powoduje silne zwiększenie szybkości utleniania stali zaworowej X53CrMnNiN208 i X55CrMnNiN208 w temperaturze 973 K (rys. 10 krzywe odpowiednio 2a i 3a) oraz niemalże katastrofalne zwiększenie szybkości utleniania w temperaturze $1173 \mathrm{~K}$ (rys. 10 krzywe odpowiednio 2 b i 3b).

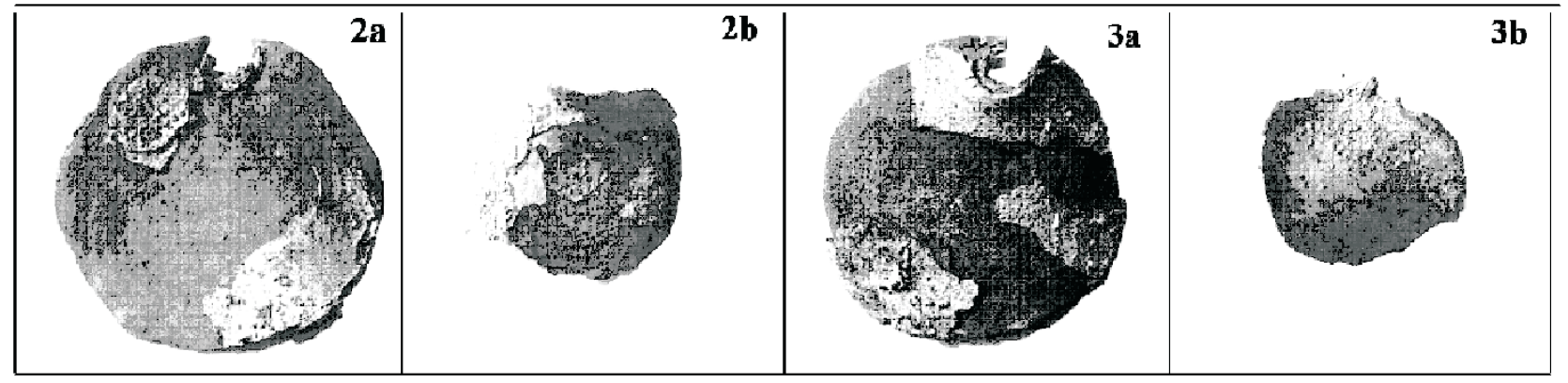

Fig. 9. Macroscopic image of the surface of the X53CrMnNiN208 sample after oxidation in the exhaust gases in the temperature of: $2 \mathrm{a}-973 \mathrm{~K} / 600$ hours and $2 \mathrm{~b}-1173 \mathrm{~K} / 80$ hours and X55CrMnNiN208 sample after oxidation in the exhaust gases in the temperature of: $3 \mathrm{a}-973 \mathrm{~K} / 600 \mathrm{hours}$ and $3 \mathrm{~b}-1173 \mathrm{~K} / 80$ hours

Rys. 9. Makroskopowy obraz powierzchni próbek stali X53CrMnNiN208 po utlenieniu w gazie spalinowym w temperaturze: 2 a - 973 K/600 godz. i $2 b$

- $1173 \mathrm{~K} / 80$ godz oraz stali X55CrMnNiN208 po utlenieniu w gazie spalinowym w temperaturze: $3 a-973 \mathrm{~K} / 600$ godz. i $3 b-1173 \mathrm{~K} / 80$ godz. 
exhaust gases with a $5 \%$ content of methyl esters of higher fatty acids have shown that the lowest oxidation rate under the conditions of cyclic thermal loads in the temperature of $973 \mathrm{~K}$ and $1173 \mathrm{~K}$ has the steel of the lowest mechanical properties X33CrNiMnN238 and the highest content of $\mathrm{Cr}, \mathrm{Ni}$ and $\mathrm{Si}$ (23.40; 7.82 and $0.63 \%$ respectively) and the lowest content of Mn (330\%) (Fig. 9, curve 1a and 1b).

The investigations into the oxidation rate have also shown that a simultaneous increase in the $\mathrm{Mn}$ content from $3,30 \%$ to 10,30 and $7.57 \%$ [9] and the reduction of the content of $\mathrm{Cr}$ from $23.40 \%$ to 20.50 and $20.30 \%$ (i.e. the values lower than those ensuring selective oxidation of $\mathrm{Cr}[10,11])$ as well as a reduction of the content of $\mathrm{Cr}$ (increasing the diffusion coefficient) in the Ni steel from $7.82 \%$ to 4.10 and $2.08 \%$ [12] and Si from $0.63 \%$ to 0.30 and $0.17 \%$ results in a great increase in the oxidation rate of the valve steel X53CrMnNiN208 and X55CrMnNiN208 in the temperature of $973 \mathrm{~K}$ (Fig. 10 curves $2 \mathrm{a}$ and $3 \mathrm{a})$ and an almost destructive increase of the oxidation rate in the temperature of $1173 \mathrm{~K}$ (Fig. 10 curves $2 b$ and $3 b$ ).

Paper reviewed/Artykut recenzowany

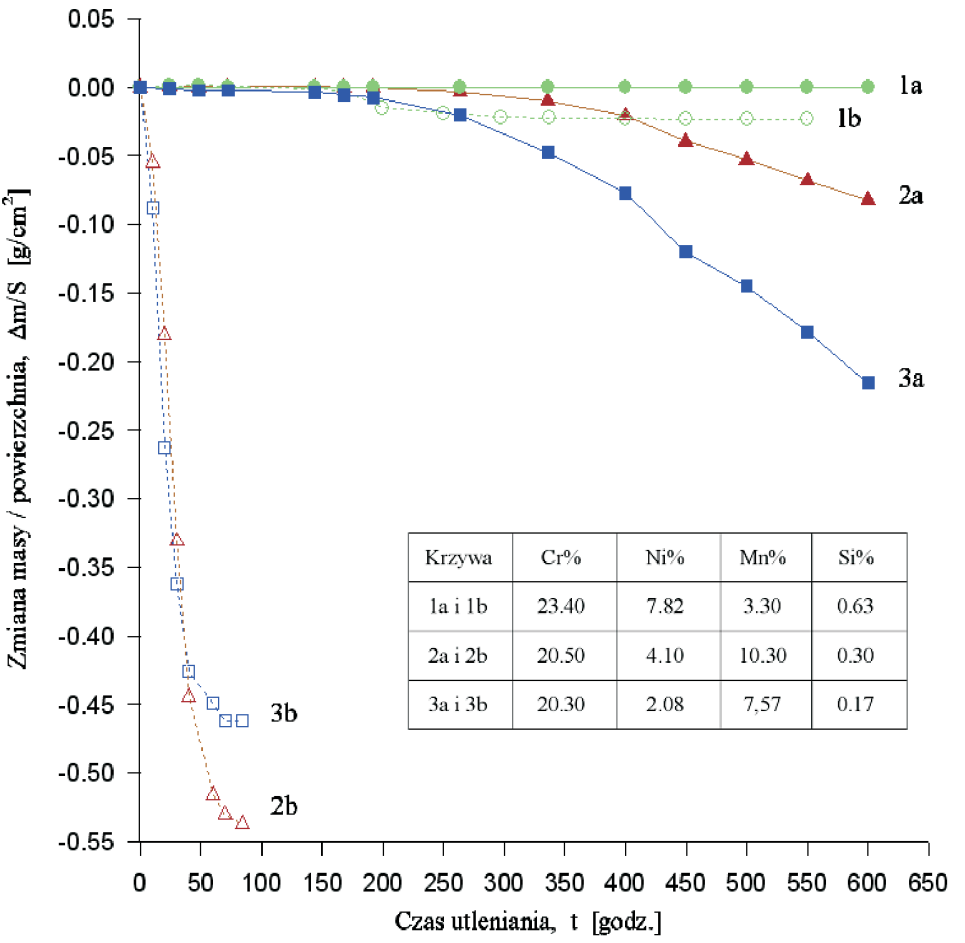

Fig. 10. Oxidation rate of austenitic high alloy steel: $1-\mathrm{X} 33 \mathrm{CrNiMnN} 238$, $2-\mathrm{X} 53 \mathrm{CrMnNiN} 208$ and $3-\mathrm{X} 55 \mathrm{CrMnNiN} 208$ under the conditions of cyclic thermal shocks in the diesel exhaust gases containing $5 \%$ biocomponents in the temperature of: $\mathrm{a}-973 \mathrm{~K}$ and $\mathrm{b}-1173 \mathrm{~K}$

Rys. 10. Makroskopowy obraz powierzchni próbek stali X53CrMnNiN208 po utlenieniu $w$ gazie spalinowym $w$ temperaturze: $2 a-973 \mathrm{~K} / 600$ godz. $i 2 b-1173 \mathrm{~K} / 80$ godz oraz stali X55CrMnNiN208 po utlenieniu $w$ gazie spalinowym $w$ temperaturze: $3 a-973 \mathrm{~K} / 600 \operatorname{godz}$. $i 3 b-1173 \mathrm{~K} / 80 \operatorname{godz}$

\section{Bibliography/Literatura}

[1] Kasedorf J.: Zasilanie wtryskowe olejem napędowym. WKiE, Warszawa 1990

[2] Bernhardt M., Dobrzyński S., Loth E.: Silniki spalinowe. WKiE, Warszawa 1988

[3] Merkisz J.: Ekologiczne problemy silników spalinowych, tom I i II. Wyd. Politechniki Poznańskiej, 1999.

[4] Adamczyk J.: Metaloznawstwo teoretyczne. Własności mechaniczne, Wyd. Politechniki Śląskiej, 1989.

[5] Norma PN-EN 10098 - 1:2001. Stale i stopy zaworowe w silniku spalinowym.

[6] Naumienko D., Singheiser L., Quadakkers W.J.: Oxidation Limited of FeCrAl Based Alloys During Thermal Cyclie, in Proceedings of an EFC Workshop, Frankfurt/Main 1999, pp. 287-306, ed. by M. Schultze and W.J. Quadakkers.

[7] Mrowec S., Weber T.: Korozja gazowa metali. Wydawnictwo Śląsk, 1976.

[8] Mrowec S.: Kinetyka i mechanika utleniania stali. Wydawnictwo Śląsk, 1982.

Mariusz Wisła, MSc. - research in the Engine Research Department, BOSMAL Automotive Research and Development Institute Ltd in Bielsko-Biała.

Mgr Mariusz Wisła - specjalista d/s Badań w Zakładzie Badań Silników, Instytut Badań i Rozwoju Motoryzacji BOSMAL Sp. z o.o., Bielsko-Biała. e-mail:mariusz.wisla@bosmal.com.pl
[9] Mrowec S., Werber T.: Modern Sc-Resistant Materials, National Bureau of Standards and National Science Foundation, Washington D.C., 1982.

[10] Kofstad P.: High Temperature Corrosion, Elsevier Applied Science, London and New York, 1988, p.389.

[11] Rahmel A.: Z. Elektrochem. 66, 363-371, 1961.

[12] Wood G., Hobby M., Vaszko B.N.: J. Iron Steel Inst. 202, 685-691, 1964

Andrzej Suchecki, DEng. - Engine Testing Laboratory Manager at BOSMALAutomotive Research and Development Institute Ltd. of Bielsko-Biała, Poland.

Dr inż. Andrzej Suchecki-Kierownik Pracowni Badań Stanowiskowych Silników w Instytucie Badań i Rozwoju Motoryzacji BOSMAL Sp. z o.o. w Bielsku-Białej. e-mail: andrzej.suchecki@bosmal.com.pl

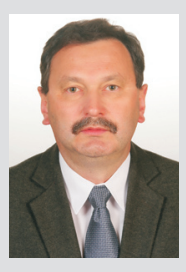

Krzysztof Adamaszek, DEng. - doctor in the Material Testing Department, BOSMAL Automotive Research and Development Institute Ltd in Bielsko-Biała.

Dr inż. Krzysztof Adamaszek - adiunkt w Zaktadzie Materiałoznawstwa, Instytut Badań i Rozwoju Motoryzacji BOSMAL Sp. z o.o., Bielsko-Biała. e-mail: krzysztof.adamaszek@bosmal.com.pl 